\title{
(Re)discovering the Gaulcross hoard
}

\author{
Gordon Noble ${ }^{1, *}$, Martin Goldberg ${ }^{2}$, Alistair McPherson ${ }^{3}$ \\ \& Oskar Sveinbjarnarson ${ }^{1}$
}

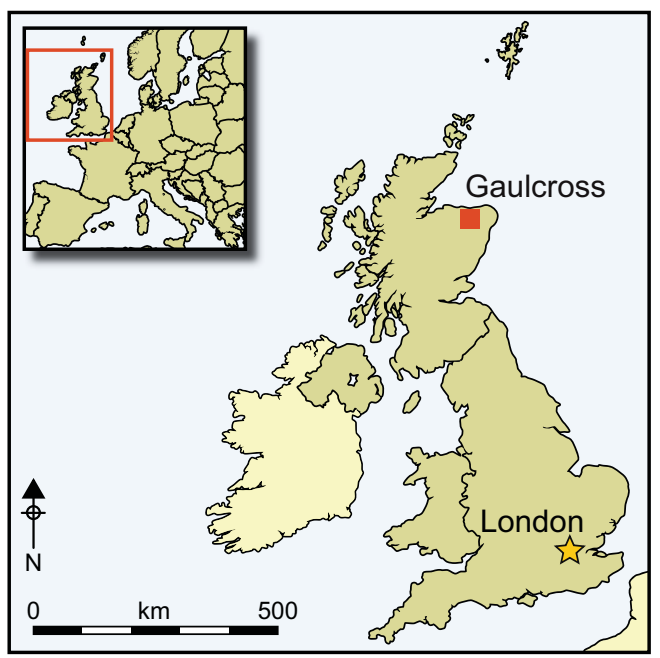

Modern excavations can sometimes provide surprising new insights on antiquarian finds of metalwork. The Pictish silver hoard from Gaulcross in north-eastern Scotland provides an excellent example. Recent fieldwork, including metal-detecting, has clarified the size and composition of the hoard, and uncovered 100 new silver items, including coins, fragments of brooches and bracelets, ingots and parcels of cut, bent and broken silver known as Hacksilber. Comparisons with other hoards and with Pictish symbol stones illustrate the circumstances and date of deposition, the origin of the silver and the forms of society emerging in Scotland in the post-Roman period.

Keywords: Scotland, late Roman, early medieval, Pictish, silver hoard, Hacksilber, metaldetecting

\section{Introduction}

During the eighteenth and nineteenth centuries, many antiquities were both discovered and destroyed through processes of agricultural improvement and expansion, and their discovery was often inadequately reported. As a result, although these treasures are often the highlights of public displays, we know relatively little about them compared to the levels of information recovered from modern excavations. Here, we highlight the potential of reinvestigating antiquarian finds for research purposes, using modern investigative techniques to provide information otherwise lacking for so many old finds. The article outlines a project that revisited the findspot of a Pictish silver hoard at Gaulcross, Aberdeenshire (Figure 1). Only three items survived from the original 1838 discovery, but fieldwork carried out in spring 2013 uncovered 100 new finds of silver: late Roman coins and military equipment, personal ornaments including brooch and bracelet fragments, ingots and Hacksilber parcels (pieces of cut, bent and broken silver often found in hoards—-see Hunter and Painter 2013 for a more

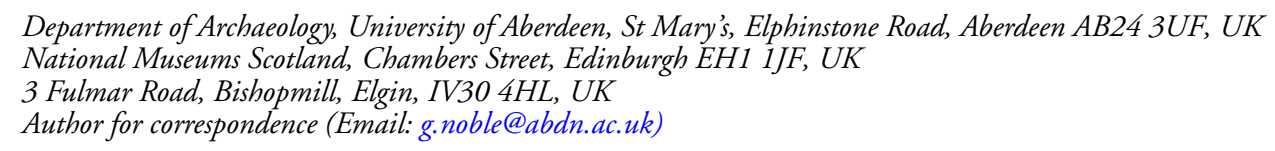




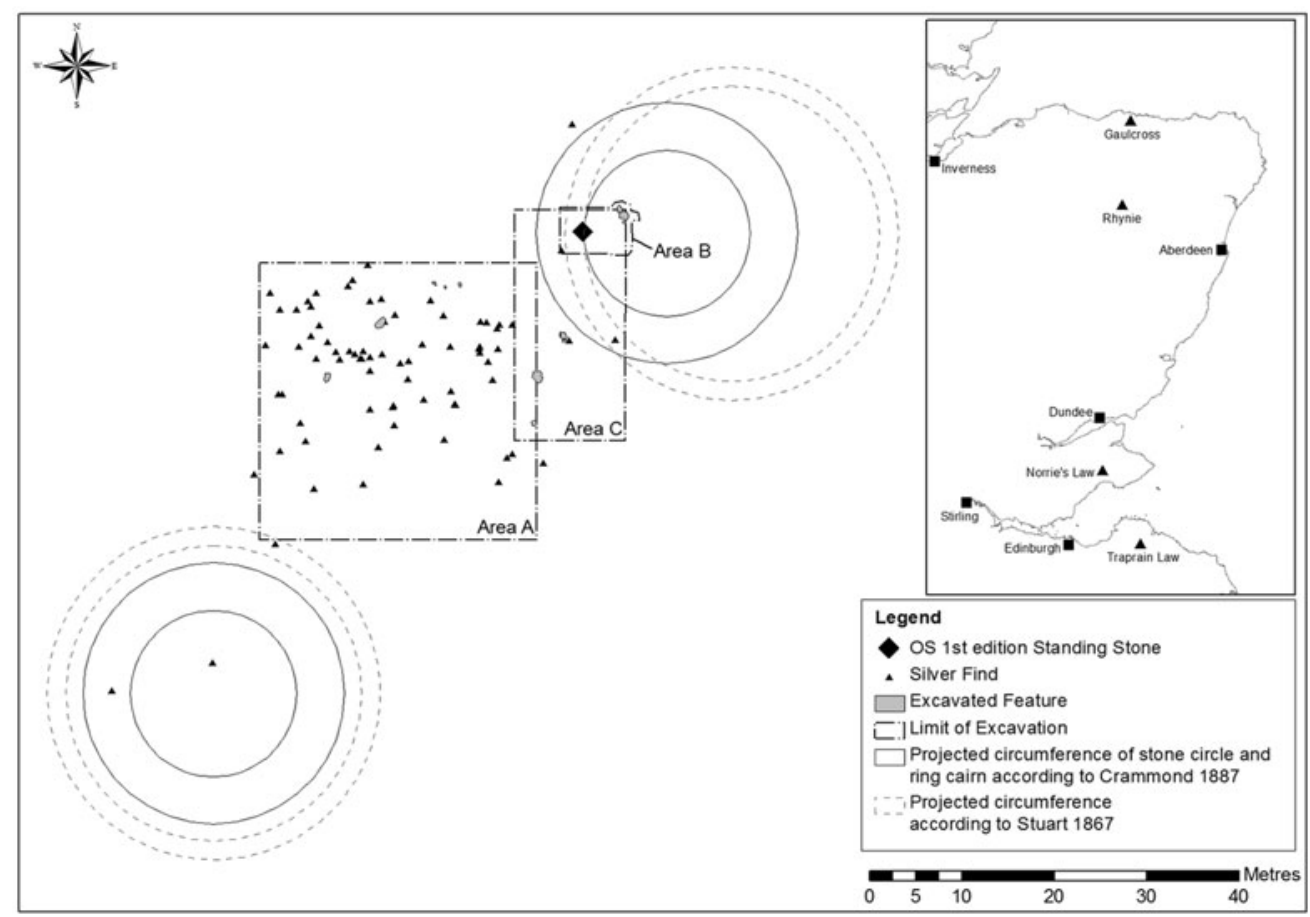

Figure 1. Location map of the findspot (inset), the projected position of the two stone circles at Gaulcross North, and the location of the recent silver finds at the site (produced by Oskar Sveinbjarnarson).

detailed definition). The new fieldwork has revealed that the Gaulcross hoard was much larger than previously thought and is now the northernmost (pre-Viking Age) Hacksilber hoard in Europe and one of only two comparable hoards known in Scotland. The discussion here focuses on the composition of the hoard, its date and the insights it can provide into the character of society in northern Britain in the late Roman and post-Roman periods.

\section{The original discovery of the hoard}

The Gaulcross hoard was discovered in 1838 at Ley Farm, Aberdeenshire (north-east Scotland), in a field that contained two stone circles. In 1837, James Lawtie gained the tenancy of the farm at Gaulcross and began improving the land. The stone circles were ruthlessly removed, with some of the stones blown up using dynamite. Only one monolith of the northern circle was still standing at the time of the first account of the hoard by John Stuart (1867: 74-75). He indicates that the silver hoard was found on the southern side of the northern circle amongst the boulders of the ring-cairn. Stuart confirms that other "pins and brooches" were found, but only illustrates three objects (Stuart 1867: 75). These three surviving items from the original discovery are a hand-pin (so-called because of its resemblance to a clenched fist), a spiral bracelet and a length of silver chain (Figure 2). These were given by the landowner, Sir Robert Abercromby, to Banff Museum, Aberdeenshire, 


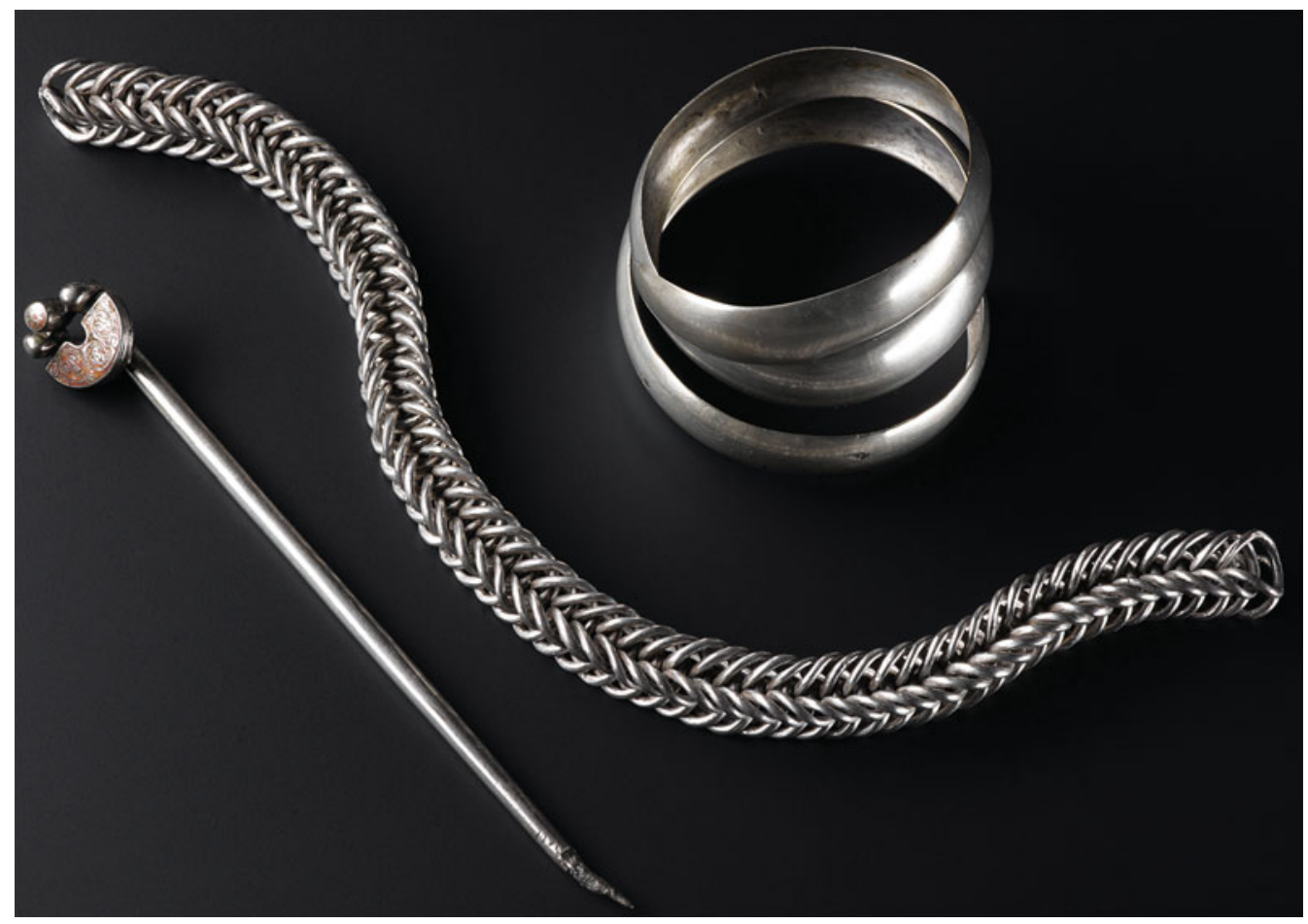

Figure 2. The surviving objects from the nineteenth-century Gaulcross hoard find (C) National Museums Scotland).

and are now on loan and displayed in the National Museum of Scotland in Edinburgh (Stevenson \& Emery 1964). The Reverend William Cramond also reported that the hoard was found south of the remaining monolith, which was on the western side of the north circle. Echoing Stuart, Cramond suggested that the hoard included other pins, buckles and brooches (Cramond 1887: 92).

\section{Revisiting the Gaulcross hoard}

Gaulcross is now an intensively farmed arable field in rural Aberdeenshire; nothing is evident of the stone circles. In spring 2013, two projects in Scotland came together to investigate the findspot of the hoard. The Northern Picts project (established 2012) at the University of Aberdeen, a field-based initiative targeting key Pictish sites in northern Scotland, and National Museums Scotland Glenmorangie Research Project (established 2008), which has been promoting material culture approaches to the study of early medieval Scotland. The initial aim of this joint venture was to investigate whether new contextual information could be provided for the important antiquarian find at Gaulcross. Fieldwork began with a geophysical survey. Metal-detecting was also planned with the aim of addressing the level of antiquarian recovery of the hoard and to identify any additional small fragments of the hoard that may have been missed by the original finders. On the second day, Alistair McPherson, a local metal-detectorist working with the project, found three late Roman silver siliquae (C) Antiquity Publications Ltd, 2016 
A

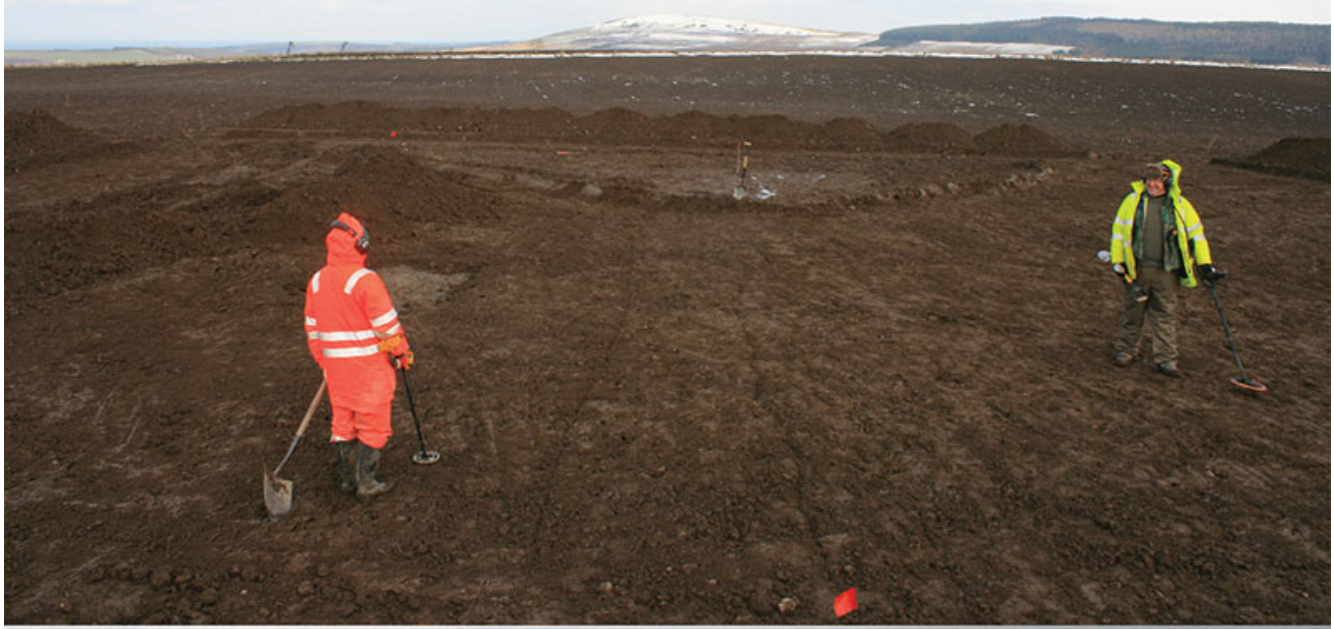

B

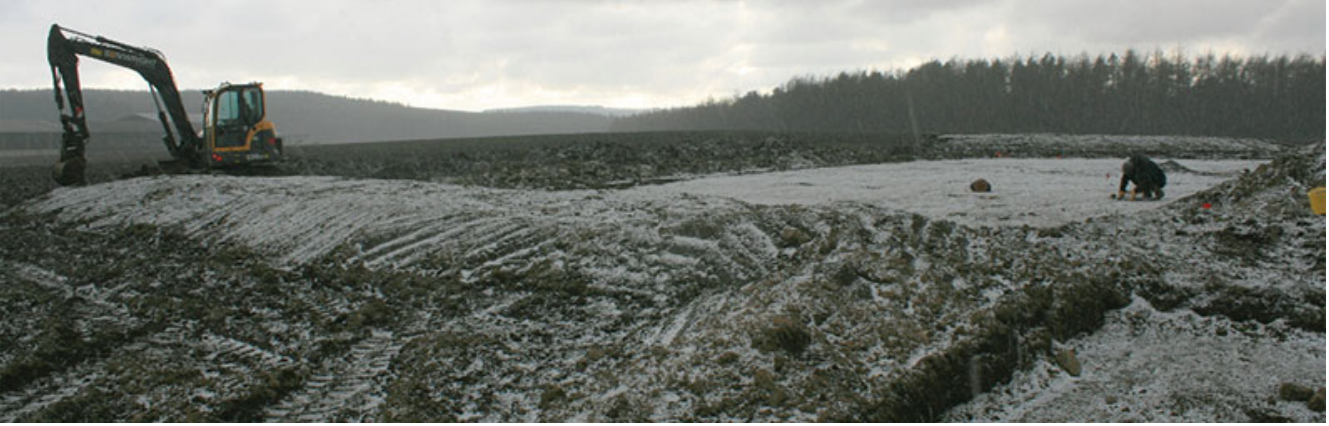

Figure 3. A) The excavation underway; the topsoil was stripped back by machine in spits to allow detecting at different levels; B) the subsoil was also detected, cleaned and its features recorded and excavated.

(Roman silver coins of the fourth and fifth centuries AD), pieces of folded Hacksilber, a silver strap-end and part of a silver bracelet.

With these early successes the project stepped up a gear as the field was due to be ploughed and planted within a week. Geophysical survey was extended over $31500 \mathrm{~m}^{2}$ but revealed little, so the approach quickly focused on metal-detecting (Figure 3). Finds were plotted using a differential GPS (dGPS), providing accurate 3D recording. Over the next three days, metal-detecting allowed the finds scatter to be plotted, and a large trench was opened over the most concentrated area. The opening of the trench followed a two-stage process,

(C) Antiquity Publications Ltd, 2016 
with approximately half of the plough-soil removed at first to allow detecting to be carried out at different levels. The depth of plough-soil was around $0.3 \mathrm{~m}$, with detection from the metal-detectors penetrating around $0.2 \mathrm{~m}$ deep maximum. The trench was subsequently cleaned, planned and the position of features recorded. Careful excavation demonstrated that all of the finds were located in the modern plough-soil (Figure 1: area A). A smaller trench was also opened at the recorded position of the last standing stone of Gaulcross North stone circle (area B).

A small number of features were identified during the excavation phase from 21-25 March 2013, but none can be linked directly with the silver finds. Boulders found in area B may have been part of the ring cairn of the stone circle; a number of lithics were also found. A few prehistoric features were identified, one dating to the early Neolithic and another to the Middle Bronze Age (1670-1500 cal BC). The latter conceivably related to the construction or use of the stone circle, but few other traces of it were found; the agricultural improvement of Lawtie and his labourers had been comprehensive.

Excavation only occurred once each area had been thoroughly swept by the detectors. Subsequent detecting of the spoil heaps and additional visits have shown that almost all artefacts were detected using this method. Over the next 18 months, Alistair McPherson repeatedly detected the fields to ensure that all the silver was recovered. Subsequent detecting produced 14 additional finds, again all within the topsoil, widely scattered and at the margins of the main artefact scatter excavated in spring 2013. Indeed, further detecting and an additional trench opened in September 2014 (area C) produced no new finds or features of significance.

Antiquarian reports suggest that the hoard was at only a slight depth below the surface, "found between two stones" (Stuart 1867: 75), and the recent finds were all within the modern plough-soil. It seems probable that the dispersal of the fragments of Hacksilber began during the extensive improvements to the field in 1838, which led to the initial discovery, and that subsequent ploughing dispersed the silver further. The lack of remaining evidence for the stone circle and the destruction of the stones of the circles are testament to the vigour of improvement and the intensive ploughing carried out since that time. Many small fragments of Hacksilber and other objects had been missed or dispersed before the hoard was discovered by the original finders. Careful mapping of the finds by dGPS in three dimensions will allow subsequent studies of the dispersal and survival of the hoard material in the plough-soil.

\section{Character and composition of the hoard}

The new fieldwork at Gaulcross has entirely changed our knowledge of the scale and character of this hoard. One hundred new silver items were recovered: mostly small fragments of sheet silver, hacked fragments of objects and, occasionally, more diagnostic and intact objects (Figure 4). We have confirmed that the three surviving items were part of a larger Hacksilber hoard similar to the only other comparable hoard known in Scotland: the Norrie's Law hoard from Fife (Figure 5). Large silver hand-pins found in both had always linked the two hoards (Youngs 2013), but within the new finds from Gaulcross there are more recognisable late Roman objects than in the Norrie's Law hoard, such as hacked dish fragments, spoon

(C) Antiquity Publications Ltd, 2016 


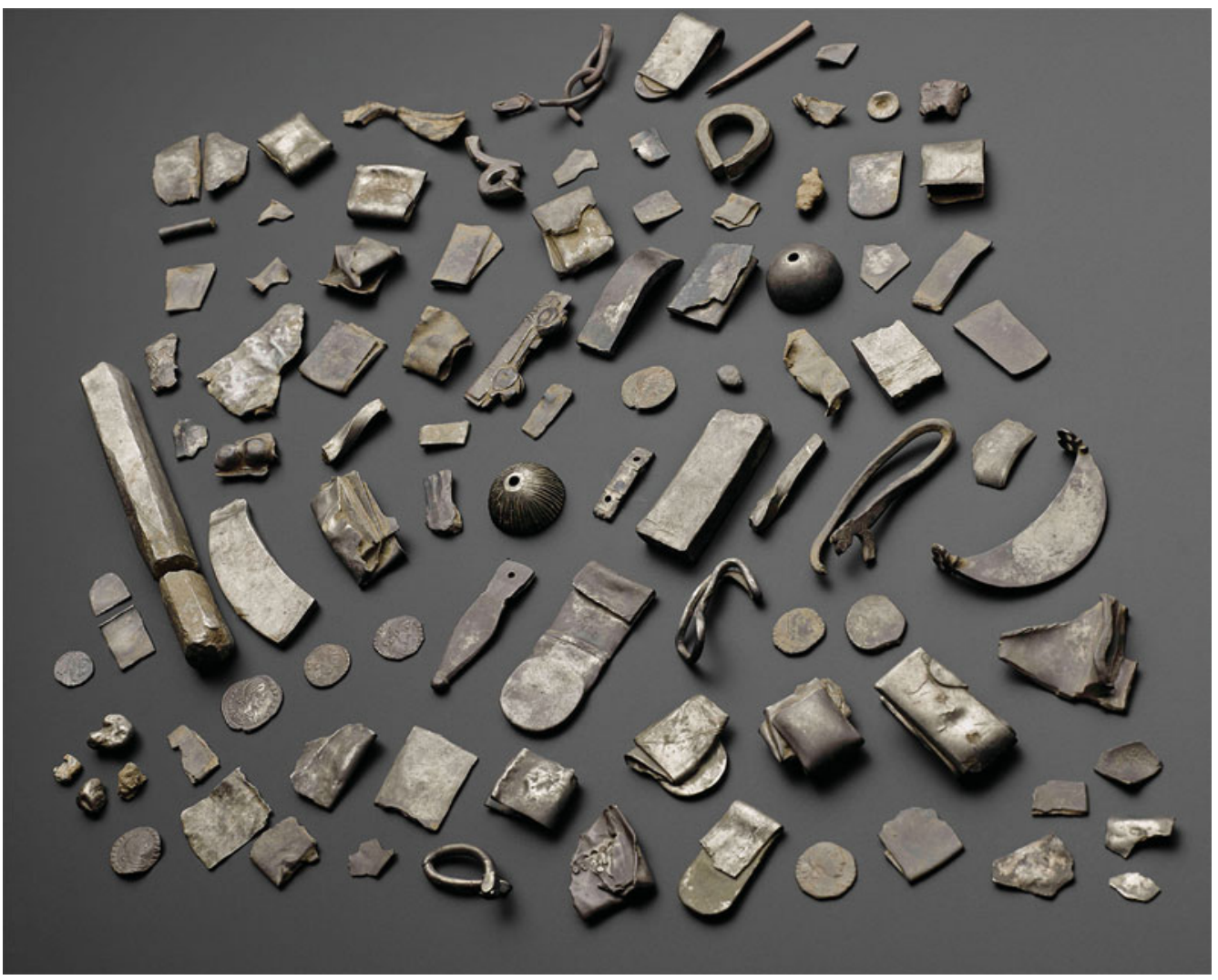

Figure 4. The Gaulcross silver hoard, including a silver ingot, Hacksilber and folded bracelets (C) National Museums Scotland).

handles and a strap-end/belt fitting. There are also clipped siliquae, a British phenomenon that involves removing the edges of fourth-century Roman silver coins in order to stretch out increasingly diminishing supplies of silver during the fifth century $\mathrm{AD}$ when coinage was no longer being imported into Britain (Guest 2013). Not all objects from Gaulcross have been hacked. Intact ornaments include a lunate/crescent-shaped pendant (Figure 6a) with two double-loops at either end, perhaps for suspension from a small-gauge, double-link chain, and two hemispheres that may have originally formed one ornament, perhaps a hollow, spherical bead or pinhead (Figure 6b).

A number of the finds are unique or very rare. For example, only one confirmed silver ingot was previously known from Pictland, from excavations at the hillfort of Clatchard Craig (Close-Brooks 1986). The Gaulcross hoard includes two distinct types of ingots: Dsectioned, and rectangular-sectioned, comparable to those found in other Hacksilber hoards, such as that from Coleraine, Northern Ireland (Marzinzik 2013). The contents of both the Gaulcross and Norrie's Law hoards call into question our modern categorisation of Roman and 'native'/'Pictish' identities. Fragments of two penannular brooches in the Gaulcross hoard are object types with a wide currency in late Roman and early medieval Britain and

(C) Antiquity Publications Ltd, 2016 


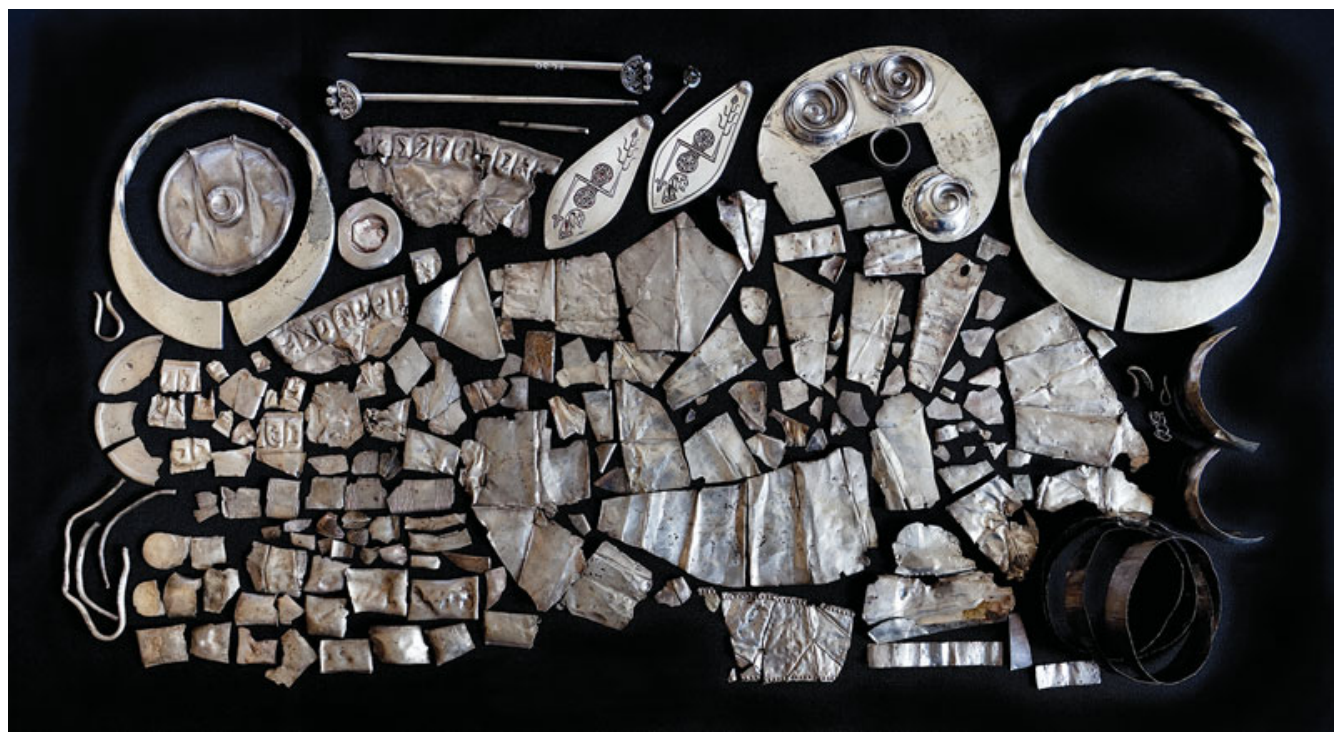

Figure 5. The Norrie's Law hoard, Fife, central Scotland (C) National Museums Scotland).

Ireland, but these objects span that historical transition. One is a flattened terminal of a penannular brooch with a twisted hoop of a type only otherwise found in the Norrie's Law hoard (top left in Figure 5). The other is a substantial portion of a small, type F zoomorphic penannular brooch (Figure 6c). These are rare in both form and material. Before the recent Gaulcross discovery, the Norrie's Law twisted penannular hoops were unique; and although the zoomorphic penannular brooch is much more widely distributed in bronze across Britain and Ireland, it is very unusual in silver.

A large proportion of the Hacksilber comes from bracelets in a variety of shapes, widths and diameters, chopped up, folded and sometimes bundled into packages. These provide a further parallel to the many similar fragments found in the Norrie's Law hoard. Two of the Gaulcross bracelet packages had late Roman siliquae pinched between the terminal and a fold (Figure 6d). The cultural origins of these bracelets (Roman or indigenous) will be a key question for future research. Further analytical study of the objects in both hoards will undoubtedly reveal much about the transition from late Antiquity to the early medieval period in this part of northern Europe.

\section{Discussion}

The Gaulcross hoard can now be studied alongside two other pre-Viking Age Hacksilber hoards from Scotland: Traprain Law, East Lothian, containing only late Roman items, and Norrie's Law, Fife, a mix of late Roman and non-Roman objects. Traprain Law is the largest known hoard of late Roman Hacksilber, buried at some point in the fifth century AD inside a hillfort (Curle 1923). It weighs approximately $22 \mathrm{~kg}$ and is dominated by fragments of dishes, flagons and platters, their composition typical of high-purity late Roman silver. This hoard has been the focus of a recent international research project at National Museums

(C) Antiquity Publications Ltd, 2016 

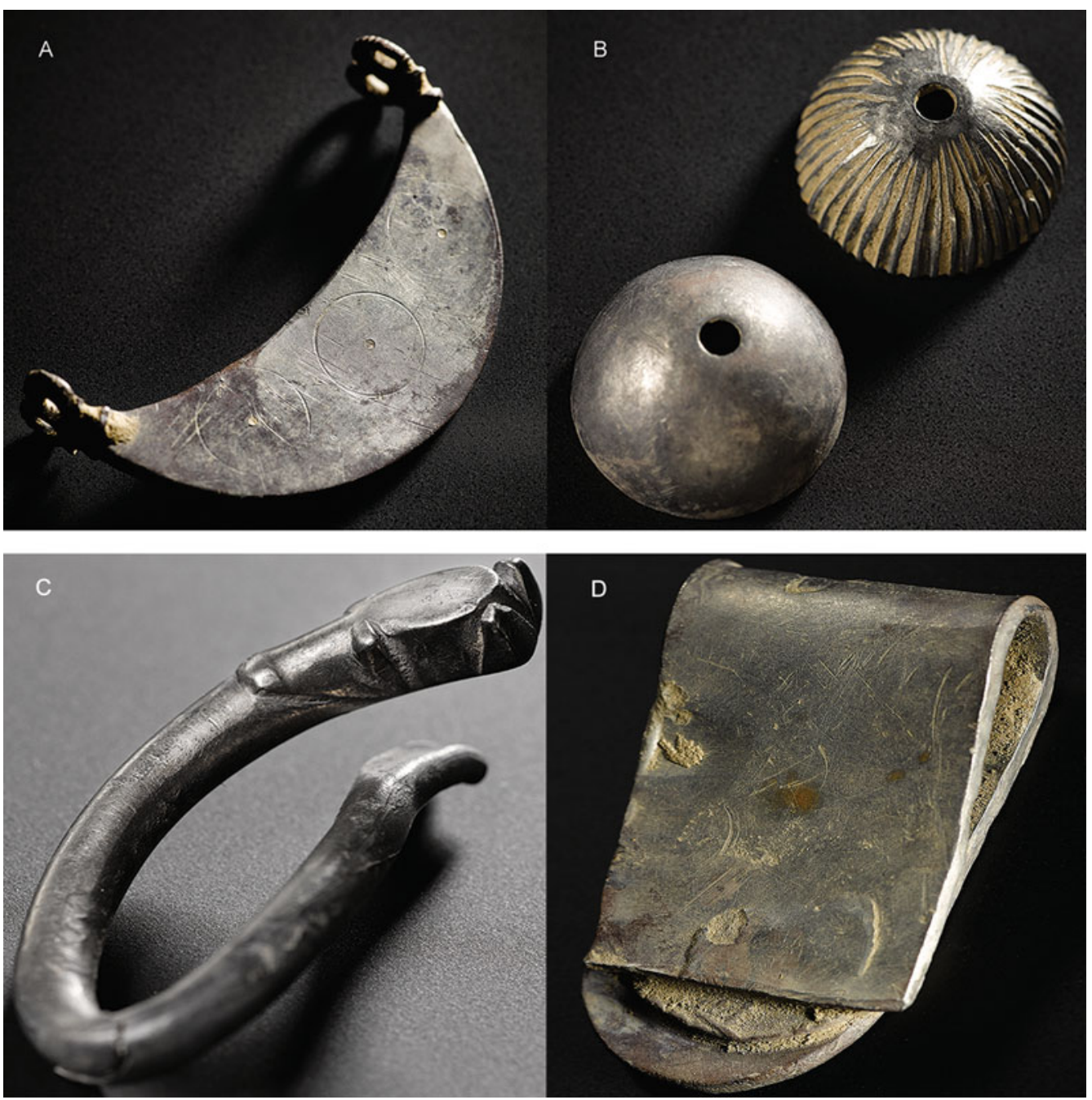

Figure 6. Finds from Gaulcross: A) the lunatelcrescent-shaped pendant with two double-loops; B) silver hemispheres; C) a small, zoomorphic penannular brooch; D) one of the bracelet fragments with a Late Roman siliquae pinched inside (C) National Museums Scotland).

Scotland (Hunter \& Painter 2013). Analytical science (including PIXE and XRF analysis) has demonstrated that the composition of late Roman silver in the Traprain Law hoard and the silver in the Norrie's Law hoard can be differentiated based on trace elements as much as the quality of the silver (Tate \& Troalen 2009), and the composition of the Gaulcross silver will be a key area for future research.

The closest comparison for the contents of the Gaulcross hoard is the Norrie's Law hoard (Figures $4 \& 5$ ), discovered around 1819 by a labourer digging for sand at the base of a large prehistoric cairn in Fife. As with the Gaulcross hoard, only a fraction of the Norrie's Law hoard survives: just $750 \mathrm{~g}$ of the $12 \mathrm{~kg}$ of silver estimated to have been found originally

(C) Antiquity Publications Ltd, 2016 
(Graham-Campbell 1991). The majority of the silver was immediately dispersed, sold and melted down. The hoard now consists of around 170 pieces and includes two hand-pins, a plaque decorated with Pictish symbols, two pennanular brooches with twisted hoops, a complete spiral finger-ring and fragments of others, chain fragments, decorated fittings, many fragments of bracelets, and Hacksilber, including an inscribed late Roman spoon bowl (Stevenson 1955; Blackwell \& Goldberg in press). As at Gaulcross, Roman coins were also found, and although they are now lost, three late-fourth-century Roman siliquae have recently been identified from an early drawing of the hoard (Bland et al. 2013: 132; Blackwell \& Goldberg in press). The most remarkable object from the Norrie's Law find is the plaque decorated with Pictish symbols that are more usually found on standing-stone monuments across northern and eastern Scotland. The symbols are as yet undeciphered, but they probably mark personal identities and may have been a form of communication, serving a similar purpose to contemporary inscribed stones using ogam and Latin in Ireland and Wales (Samson 1992; Forsyth 1997).

\section{Dating the hoard(s)}

The dating of both the Gaulcross objects and the Norrie's Law hoard has been much debated. The Gaulcross hoard has generally been seen as earlier than Norrie's Law, perhaps dating to the sixth to seventh centuries AD (Stevenson \& Emery 1964; Youngs 1989: 26; GrahamCampbell 1991: 241). The dating of the Norrie's Law hoard has seen more discussion, with results ranging from the late fourth or fifth century (Laing 1990: 41) to the eighth century $\mathrm{AD}$ (Stevenson 1955: 110). There is a greater quantity of late Roman items in the new finds from Gaulcross, but it is also uncertain how many Roman objects were lost from Norrie's Law due to its dispersal. The similarities between the two hoards means that discussion of their date has often been intertwined.

A date in the seventh- to eighth-century range for the deposition of the Norrie's Law hoard has been generally accepted, based primarily on art-historical analysis of the symbols on the silver plaque (Figure 5) (Henderson 1989: 211; Graham-Campbell 1991: 255; Henderson $\&$ Henderson 2004: 88), and on one of the hand-pins. Graham-Campbell, for example, compared the juxtaposition of the Z-rod on the back of the hand-pin and a small cross detail on the front with class II Pictish cross-slabs dating to the seventh century or later. Recent research has, however, shown this hand-pin to be a nineteenth-century copy of the other large Norrie's Law hand-pin, with the addition of a Z-rod on the back (Goldberg \& Blackwell 2013). One of the two plaques has also been shown to be a nineteenth-century copy.

The symbols on the remaining plaque from Norrie's Law consist of a double-disc and Z-rod, and a 'beast-head' shown in profile. Both Stevenson (1955: 110; Stevenson \& Emery 1964: 208), Graham-Campbell (1991: 255) and Henderson (1989: 211; Henderson \& Henderson 2004: 88) compared the latter symbol to a dog motif in the Lindisfarne Gospels. A closer comparison is found on a Pictish symbol stone from Rhynie, Aberdeenshire (number 5), which depicts the same two symbols of a beast-head, doubledisc and Z-rod, but with the addition of a mirror-and-comb symbol (Figure 7). Indeed, the art-historical comparison with the Lindisfarne Gospels is misleading. The beast on

(C) Antiquity Publications Ltd, 2016 
the Norrie's Law plaque and on the Rhynie stone is not a dog; in both cases, flippers are depicted, and it is more readily identifiable as some form of sea- or water-creature.

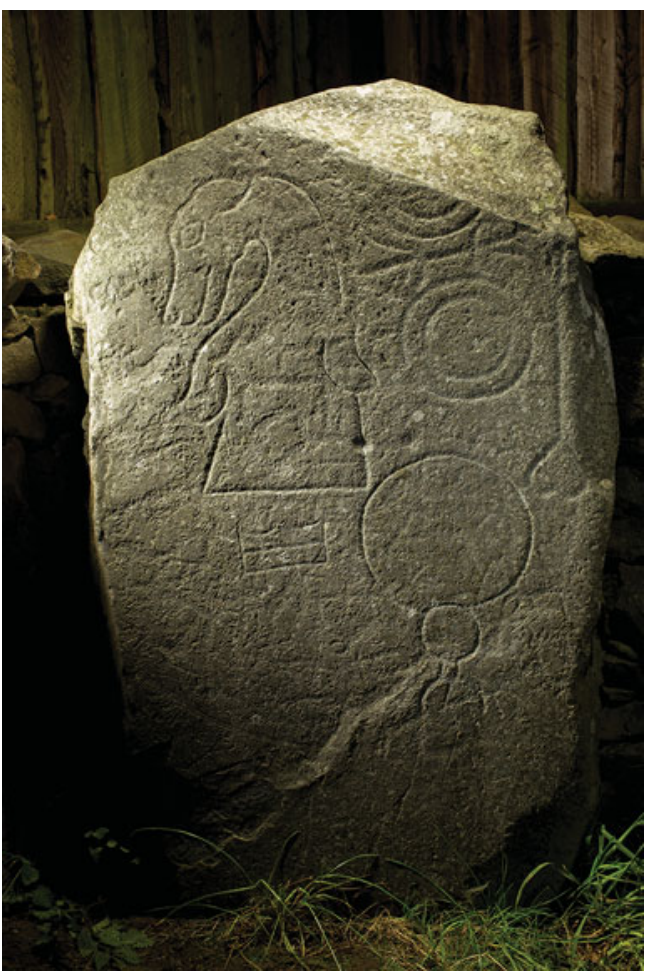

Figure 7. Rhynie 5: a symbol stone showing the 'beast' head, similar to that depicted on the silver plaque from Norrie's Law (C) Michael Sharpe).
As with so many Pictish symbol stones, the context of the Rhynie symbol stone is uncertain given that it was found in the foundations of the later parish church. Recent excavations up-slope from the church have, however, found an extensive, high-status settlement in association with the findspots of three other stones, a contemporary cemetery that extends towards the modern village and the findspots of two further stones. Over 20 radiocarbon dates for the Pictish phases of the settlement and cemetery all point to a fifth- to sixth-century $\mathrm{AD}$ date for this major complex (Noble et al. 2013). A clay mould for the production of a hand-pin has been recovered from Rhynie, providing additional material links to the two silver hoards.

The Pictish symbol stone, Rhynie 5, is the best parallel for the symbols on the Norrie's Law plaque, and the recent excavations of the associated complex suggest a fifth- to sixth-century $\mathrm{AD}$ date. The number of Roman finds in the Gaulcross hoard (and increasingly recognised in Norrie's Law) also suggests that an earlier date for both hoards must be considered. This would place them within a wider, northern European context of hoards from Denmark of fifth- to sixth-century date that also contain a mixture of Roman and non-Roman objects (Painter 2013: 226; Blackwell \& Goldberg in press). Although the evidence for re-dating is tentative, more detailed analysis will again hopefully narrow the date of deposition of the two hoards.

\section{Europe's northernmost pre-Viking Age Hacksilber hoard}

As well as re-examining the composition and dating of the hoards from Gaulcross and Norrie's Law, the Glenmorangie research project at the National Museums of Scotland will address the biography of these hoards over the next three years. Certainly some of the objects, such as fragments of vessels from Roman silver dining sets and artefacts with late Roman military associations, had long histories. Alongside these were fragments of items such as penannular brooches, made locally and found across Britain and Ireland. Silver was not mined in Scotland during this period, instead it had its origins in the Hacksilber from the 
late Roman world, as exemplified by the Traprain Law hoard. The differing compositions of individual objects in the three Scottish Hacksilber hoards will show how, through time, late Roman silver was recycled and re-cast into high-status objects that underpinned the development of elite society in the post-Roman period. During the process of recycling, the Roman silver was remade into new objects, but its origin may not have been entirely forgotten. Some of these later objects may have also directly referenced the late antique world, with items such as hand-pins showing the adaptation of late Roman military styles, both in terms of design and decorative techniques (Gavin 2013: 430; see also Youngs 2013: 415). As Gavin notes, the use of Roman models may have been intended to evoke military prowess and ostentation amongst elites in early medieval Britain and Ireland (Gavin 2013: 433).

In relation to the ultimate origins of the Roman items in these hoards, interpretations of the distribution of silver into non-Roman hands has ranged from looting, trade and bribes to natives, to military pay for native groups in contact with the Romans. Hunter (2007a $\&$ b), for example, has argued for the deliberate use of bribes and subsidies by the Romans in Scotland to build up and destabilise the native society. Recent scholarship, however, has focused on Hacksilber as evidence of indigenous individuals or groups serving in the late Roman military (e.g. Guggisberg 2013: 213). The 'parcels' of silver from Gaulcross, including coins clasped between bracelet fragments, do indeed suggest that standardised weights of silver could have been used as a means of payment. Whether this was from direct payment for military service in the late Roman army, or as bribes to leaders of native war bands in the late fourth or early fifth century $\mathrm{AD}$, or due to exchange between indigenous elites themselves, remains a moot point (Painter 2013: 230). Over time, this silver made its way into Hacksilber hoards.

\section{The northern Picts}

Looking at the more regional context in Pictland, this new discovery adds to the growing evidence for the importance of northern Pictland in the post-Roman period. Studies by Alex Woolf $(2006,2007)$ have relocated Fortriu, the Pictish kingdom most frequently cited in later annals, to the Moray Firth region of northern Scotland, rather than central Scotland as previously thought. The iconic Pictish class I symbol stones are more common in northern Pictland, and the distribution of massive silver chains shows a distinctive scatter in this region, but are absent from southern Pictland (Henderson 1958; Youngs 2013: fig. 26.1). A whole series of Pictish fortifications has also been identified along the Moray coastline, including the largest known Pictish fort, at Burghead in Moray. The identification of a high-status settlement at Rhynie, Aberdeenshire, and a series of ringforts recently dated to the fifth and sixth centuries $\mathrm{AD}$ has also renewed interest in northern Pictland, an area that at times has been thought to be peripheral to the major social and political developments in northern Britain (Noble et al. 2013).

Nonetheless, in the immediate area around the Gaulcross hoard, there are few identified contemporary Pictish sites, and the region has a notable absence of symbol stones. Two forts are located nearby, but radiocarbon-dating evidence obtained as part of the Northern Picts project suggests that these are Iron Age in date. The nearest confirmed Pictish fort is

(C) Antiquity Publications Ltd, 2016 

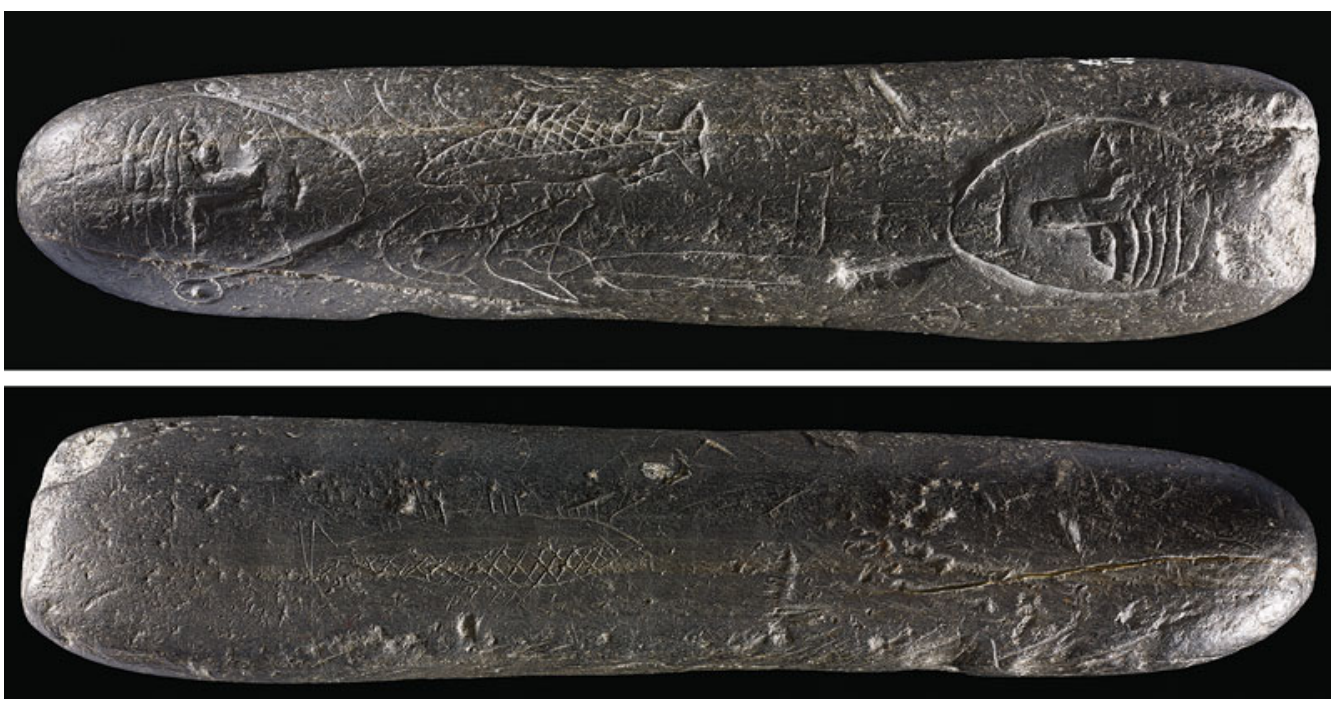

Figure 8. The Portsoy whetstone (C) British Museum).

$7 \mathrm{~km}$ along the coast at Green Castle, Portnockie. This has been partly excavated and dated to the seventh-ninth centuries cal AD (Ralston 1987). One curious object has, however, been found less than $5 \mathrm{~km}$ from the hoard site: an object known as the Portsoy whetstone (Figure 8). The object is a small cylindrical stone of phyllite, carved with human heads on either end, one apparently displayed on the end of a sword, with carvings of a fish, three crescents, an arch and tongs set between the two heads. The object is unique, but the symbols resemble those found on Pictish symbol stones. The Portsoy object has been compared to the whetstone or sceptre from the Sutton Hoo burial mound and interpreted by Enright and others as a symbol of sacral kingship (Enright 1982: 130). The Portsoy whetstone, although much simpler and less refined than the Sutton Hoo example, shows similar opposed human heads. Perhaps one of the most revealing elements of the carving is the set of tongs-an obvious reference to metalworking. At Rhynie and other Pictish sites, metalworking evidence is interpreted as an indicator of high status, used to create and support elite identities in the post-Roman period.

Some of the objects in the Gaulcross hoard were themselves almost certainly connected to elites. Items such as silver hand-pins and silver bracelets found at Gaulcross and Norrie's Law are uncommon finds. These were clearly high-status objects that would have belonged to some of the most powerful members of post-Roman society (Youngs 2013: 421). Some hoards in Denmark and Germany have been interpreted as the family treasures of emerging elites in post-Roman northern Europe (e.g. Collins 2013: 38; Painter 2013: 228; Rau 2013: 345). As with Gaulcross, the hoards of Hacksilber from Denmark include Roman and non-Roman objects, but, in contrast, many of the new finds from Denmark are found in close association with high-status central places that have evidence for imported goods and working of precious metals (Dyhrfjeld-Johnsen 2013: 321). At Gaulcross and Norrie's Law there is, as yet, no evidence of high-status settlements at the site or in the near vicinity. 
In contrast to the Danish hoards, a striking feature of the Gaulcross and Norrie's Law hoards is the isolation of the findspot. Akin to Gaulcross, there are no known Pictish settlements, forts or symbol stones in close vicinity to the Norrie's Law hoard (although a class II Christian cross-slab was discovered on the same estate). Both of the hoards are in similar topographic positions on elevated ground, with views towards the coast. If the hoards were connected to wealthy post-Roman communities then that wealth was accumulated and buried, but never reclaimed. Some hoards in the Roman Iron Age, such as the two silver denarii hoards at Birnie, Moray, buried in between a series of roundhouses, have been interpreted as gifts to the gods (Hunter 2009: 69), and the collection of second- to fourth-century AD Roman material found at Covesea Cave on the Moray coast is also best interpreted in this light (Armit et al. 2011). Gaulcross is also on a hill, less than $1.5 \mathrm{~km}$ to the west of Deskford, where a first- to third-century AD boar-headed carnyx (war trumpet) was deposited as a votive offering in a pit dug into a bog (Hunter 2001: 100). The Gaulcross hoard can perhaps be seen as part of a long-standing tradition of votive deposition in this area.

The Gaulcross and Norrie's Law hoards were both deposited at what were already ancient monuments in the Pictish period. An association with the prehistoric past as a way of bolstering the power and legitimacy of contemporary lineages is a well-known phenomenon in the early medieval period in Britain and Ireland (Bradley 1987; Driscoll 1998; see also Clarke 2007; Gleeson 2012). The appropriation of ancient places through an act of ritualised deposition could be one way in which an emerging elite connected the present to a deep ancestral past through places associated with otherworldly powers (Driscoll 1998: 143, 155). The act of deposition might also imply a rejection of the more recent past through the sacrifice of the silver objects. We need to consider the processes of accumulation, curation and deposition of the hoards as potentially embodying differing motivations, appropriate in vastly different social circumstances. Of course, these hoards could have also had much more prosaic origins. We cannot rule out the possibilities that they were the accumulated wealth of a powerful dynasty that hid their valuable raw materials for safe-keeping, and never returned. Whether a gift to the gods, the raw materials of a smith or unrecovered wealth, it seems probable that the landscape location was not fortuitous or without significance (Needham 2001); for what better location to place one's valuables than under the protection of the ancestors or the gods?

\section{Conclusions}

The new work at Gaulcross has uncovered a remarkable range of important new objects, some never before seen in Scotland. Further analysis will allow them to be fully integrated into our narratives of society in the late Roman and post-Roman centuries in northern Britain and its wider European context. The composition of the Gaulcross hoard and the close comparanda from Norrie's Law embody both the material resources of the late Roman Empire and fragments of objects associated with early medieval elite identities. They span what is traditionally seen as a historical transition from late antiquity to the new forms of society emerging in the post-Roman period.

Our work also has crucial culture resource-management implications. For example, the majority of nineteenth-century hoard findspots in Scotland are not scheduled, i.e. they (C) Antiquity Publications Ltd, 2016 
have no legal protection. The work at Gaulcross suggests that the location of important antiquarian discoveries and the information that may remain at the findspots needs legal protection as much as in situ monuments. Hobbyist metal-detecting has led to many important discoveries in recent years, but this untrained and random process of finds recovery often forces archaeologists to be reactive rather than proactive. In this difficult period for heritage management, with budgets and funding being constantly reduced, it is often a struggle to find the resources to recover the vital contextual information to understand these new discoveries. Important methodological lessons can also be drawn from our work at Gaulcross. By bringing a targeted, research-driven approach, we can greatly enrich our knowledge of artefacts that have long formed part of important national and regional collections. These treasures on public display often lack detailed contextual evidence to help more fully interpret their significance, but in many cases, vital information may await (re) discovery.

\section{Acknowledgements}

We would like to thank Charles and Helen Gray for permitting access to the land and for support in the excavation of the hoard. Thanks also to Bruce Mann and the Aberdeenshire Council Archaeology Service for advice and supporting the radiocarbon dating. Fraser Hunter and Tanja Romankiewicz assisted during a very cold excavation. Fraser and Alice Blackwell kindly read and commented on drafts of this paper. The fieldwork was funded through a donation to the University of Aberdeen's Development Trust and undertaken as part of the Northern Picts project, in association with the Tarbat Discovery Centre.

\section{References}

Armit, I., R. Schulting, C.J. KNusel \&

I.A.G. SHEPHERD. 2011. Death, decapitation and display? The Bronze and Iron Age human remains from the Sculptor's Cave, Covesea, north-east Scotland. Proceedings of the Prehistoric Society 77 251-78. http://dx.doi.org/ $10.1017 /$ S007949X00000694

BLACKWELl, A \& M. GOLDBERG. In press. Widening the context of the Norrie's Law hoard, in A. Blackwell (ed.) Scotland in early medieval Europe. Edinburgh: Society of Antiquaries of Scotland.

Bland, R., S. MoOrhead \& P. Walton. 2013. Finds of late Roman silver coins from Britain: the contribution of the Portable Antiquities Scheme, in F. Hunter \& K. Painter (ed.) Late Roman silver: the Traprain treasure in context: 117-66. Edinburgh: Society of Antiquaries of Scotland.

BRADLEY, R. 1987. Time regained: the creation of continuity. Journal of the British Archaeological Association 140: 1-17. http://dx.doi.org/10.1179/ jba.1987.140.1.1

Clarke, D.V. 2007. Reading the multiple lives of Pictish symbol stones. Medieval Archaeology 51: 19-39. http://dx.doi.org/10.1179/

$174581707 \times 224642$
Close-Brooks, J. 1986. Excavations at Clatchard Craig, Fife. Proceedings of the Society of Antiquaries of Scotland 116: 117-84.

Collins, R. 2013. Soldiers to warriors: renegotiating the Roman frontier in the fifth century, in F. Hunter \& K. Painter (ed.) Late Roman silver: the Traprain treasure in context: 29-44. Edinburgh: Society of Antiquaries of Scotland.

CRAmOND, W. 1887. The stone circles at Ley: excursion to Deskford. Transactions of the Banffshire Field Club 1887: 92-93.

Curle, A.O. 1923. The treasure at Traprain. Glasgow: Maclehose, Jackson \& Co.

DrISCOLL, S.T. 1998. Picts and prehistory: cultural resource management in early medieval Scotland. World Archaeology 30: 142-58. http://dx.doi.org/ 10.1080/00438243.1998.9980402

DYHRFJELD-JOHNSEN, M. 2013. Danish Hacksilber hoards: a status report, in F. Hunter \& K. Painter (ed.) Late Roman silver: the Traprain treasure in context: 321-38. Edinburgh: Society of Antiquaries of Scotland.

ENRIGHT, M.J. 1982. The Sutton Hoo whetstone sceptre: a study in iconography and cultural milieu. Anglo-Saxon England 11: 119-34. http://dx.doi.org/10.1017/S0263675100002581 
ForsYTH, K. 1997. Some thoughts on Pictish symbols as a formal writing system, in D. Henry (ed.) The worm, the germ, and the thorn: 85-98. Balgavies: Pinkfoot.

GAVIN, F. 2013. Insular military-style silver pins in late Iron Age Ireland, in F. Hunter \& K. Painter (ed.) Late Roman silver: the Traprain treasure in context: 427-41. Edinburgh: Society of Antiquaries of Scotland.

GleEson, P. 2012. Constructing kingship in early medieval Ireland: power, place and ideology. Medieval Archaeology 56: 1-33. http://dx.doi.org/ 10.1179/0076609712Z.0000000001

GoldberG, M. \& A. BlackWELl. 2013. The different histories of the Norrie's Law hoard, in J. Hawkes (ed.) Making histories. Proceedings of the Sixth International Insular Arts Conference, York 2011. Donington: Shaun Tyas.

Graham-Campbell, J. 1991. Norrie's Law, Fife: on the nature and dating of the silver hoard. Proceedings of the Society of Antiquaries of Scotland 121: 241-59.

GuEsT, P. 2013. Siliquae from the Traprain Law treasure: silver and society in later fourth- and fifth-century Britain, in F. Hunter \& K. Painter (ed.) Late Roman silver: the Traprain treasure in context: 93-106. Edinburgh: Society of Antiquaries of Scotland.

GugGisberG, M. 2013. Silver and donatives: non-coin exchange within and outside the Roman empire, in F. Hunter \& K. Painter (ed.) Late Roman silver: the Traprain treasure in context: 193-212. Edinburgh: Society of Antiquaries of Scotland.

Henderson, I. 1958. The origin centre of the Pictish symbol stones. Proceedings of the Society of Antiquaries of Scotland 91: 44-60.

- 1989. The arts of late Celtic Britain (AD 600-900), in B. Ford (ed.) The Cambridge guide to the arts in Britain, Volume 1: prehistoric, Roman and early medieval: 207-19. Cambridge: Cambridge University Press.

Henderson, G. \& I. Henderson. 2004. The art of the Picts: sculpture and metalwork in early medieval Scotland. London: Thames \& Hudson.

Hunter, F. 2001. The carnyx in Iron Age Europe. Antiquaries Journal 81: 77-108. http://dx.doi.org/10.1017/S0003581500072152

- 2007a. Silver for the barbarians: interpreting denarii hoards in north Britain and beyond, in R. Hingley \& S. Wills (ed.) Roman finds: context and theory: 214-24. Oxford: Oxbow.

- 2007b. Beyond the edge of the empire-Caledonians, Picts and Romans. Rosemarkie: Groam House.

- 2009. Digging Birnie, 1998-2009. The story (so far) of an Iron Age power centre, in J. Trythall \& B. Dalgarno (ed.) Beakers, bones and Birnie: 69-80. Elgin: Elgin Museum.
Hunter, F \& K. Painter (ed.). 2013. Late Roman silver: the Traprain treasure in context. Edinburgh: Society of Antiquaries of Scotland.

LAING, L. 1990. The beginnings of 'Dark Age' Celtic art, in A. Bammesberger \& A. Wollman (ed.) Britain 400-600: language and history: 37-50. Heidelberg: C. Winter.

MARZINZIK, S. 2013. The Coleraine treasure from Northern Ireland: a consideration of the fittings, in F. Hunter \& K. Painter (ed.) Late Roman silver: the Traprain treasure in context: 175-92. Edinburgh: Society of Antiquaries of Scotland.

NeEDHAM, S.T. 2001. When expediency broaches ritual intention: the flow of metal between systemic and buried domains. Journal of the Royal Anthropological Institute 7: 275-98. http://dx.doi.org/10.1111/1467-9655.00063

Noble, G., M. GondeK., E. Campbell \& M. CoOK. 2013. Between prehistory and history: the archaeological detection of social change among the Picts. Antiquity 87: 1136-50. http://dx.doi.org/10.1017/S0003598X00049917

PAINTER, K. 2013. Hacksilber: a means of exchange, in F. Hunter \& K. Painter (ed.) Late Roman silver: the Traprain treasure in context: 215-42. Edinburgh: Society of Antiquaries of Scotland.

RALSTON, I.B.M. 1987. Portknockie: promontory forts and Pictish settlement in the North-East, in A. Small (ed.) The Picts: a new look at old problems: 15-26. Dundee: University of Dundee.

RAU, A. 2013. Where did the late empire end? Hacksilber and coins in continental and northern Barbarixum, in F. Hunter \& K. Painter (ed.) Late Roman silver: the Traprain treasure in context: 339-58. Edinburgh: Society of Antiquaries of Scotland.

SAMSON, R. 1992. The reinterpretation of the Pictish symbols. Journal of the British Archaeological Association 145: 29-65. http://dx.doi.org/10.1179/jba.1992.145.1.29

Stevenson, R.B.K. 1955. Pictish art, in F.T. Wainwright (ed.) The problem of the Picts: 97-128. Edinburgh: Thomas Nelson.

Stevenson, R. \& J. EMERY. 1964. The Gaulcross hoard of Pictish silver. Proceedings of the Society of Antiquaries of Scotland 97: 206-11.

STUART, J. 1867. Sculptured stones of Scotland, volume 2. Aberdeen: Spalding Club.

TAte, J. \& L. Troalen. 2009. Investigating the Traprain Law Roman treasure. Unpublished technical report produced for Eu-Artech. Available at: https://core.ac.uk/download/ files/76/1569168.pdf (accessed 23 February 2016).

Woolf, A. 2006. Dun Nechtain, Fortriu and the geography of the Picts. Scottish Historical Review 85: 182-201.

(C) Antiquity Publications Ltd, 2016 
- 2007. From Pictland to Alba, 789-1070. Edinburgh: Edinburgh University Press.

YounGS, S. (ed.). 1989. The work of angels: masterpieces of Celtic metalwork, $\sigma^{\text {th }} 9^{\text {th }}$ centuries $A D$. London: British Museum.
- 2013. From chains to brooches: the uses and hoarding of silver in north Britain in the early historic period, in F. Hunter \& K. Painter (ed.) Late Roman silver: the Traprain treasure in context. 403-26. Edinburgh: Society of Antiquaries of Scotland.

Received: 23 March 2015; Accepted: 22 June 2015; Revised: 13 November 2015 